Note

\title{
SOURCES OF RESISTANCE TO Crinipellis perniciosa IN PROGENIES OF CACAO ACCESSIONS COLLECTED IN THE BRAZILIAN AMAZON
}

\author{
Valéria Rodrigues Lavigne de Mello Paim¹; Edna Dora Martins Newman Luz ${ }^{2 *}$; José Luís \\ Pires $^{3}$; Stela Dalva Vieira Midlej Silva ${ }^{2}$; Jorge Teodoro de Souza ${ }^{2,6}$; Paulo Sérgio Bevilaqua \\ Albuquerque ${ }^{5}$; Lindolfo Pereira dos Santos Filho \\ ${ }^{1}$ Universidade Estadual de Santa Cruz - Depto.de Ciências Biológicas - Rod. Ilhéus - Itabuna, km 16 - \\ 45.650-000 - Itabuna, BA - Brasil. \\ ${ }_{3}^{2}$ CEPLAC/CEPEC, SEFIT - Seção de Fitopatologia. \\ ${ }^{3}$ CEPLAC/CEPEC, SEGEN - Seção de Genética. \\ ${ }_{5}^{4}$ CEPLAC/CEPEC, SESOC - Seção de Sociologia - C.P.7 - 45600-970 - Itabuna, BA - Brasil. \\ ${ }_{6}^{5}$ CEPLAC/SUPOR/ERJOH - C.P. 46 - 67105-970 - Belém, PA - Brasil. \\ ${ }^{6}$ Masterfoods USA - NJ 07840 - Hackettstown - USA. \\ *Corresponding author 〈ednadora@cepec.gov.br>
}

\begin{abstract}
The witches' broom disease caused by the fungus Crinipellis perniciosa is the main phytossanitary constraint for cacao production in Brazil. The integrated management of the disease involves resistance as one of the components. The breeding program conducted by the Brazilian Institution, CEPLAC is directed toward the pyramidation of resistance genes from different sources to achieve a more durable resistance. This study aimed to identify sources of resistance in progenies of cacao accessions collected in the basins of ten Amazonian rivers and compared to progenies from the Peruvian clones 'Scavina 6' and 'Sacavina 12'. Progenies from 40 Amazonian accessions and 'Scavina' were evaluated in the field for six years for witches' broom resistance through multivariate and repeated measurement analyses evaluating the effect of progeny, area, block, year, and their interactions. There were differences in the mean number of vegetative brooms on some Amazonian progenies and 'Scavina' descendants. There was an increase in the number of vegetative brooms in the last year for 'Scavina' progenies, but that was not observed for the Amazonian progenies 64, 66, 156, 194, 195, 269 and 274. There were different gene/alleles for resistance in the Amazonian progenies in comparison to the traditional 'Scavina' accessions. These new sources of resistance will be important for pyramiding resistance genes and consequently increasing the stability and durability of the resistance to witches' broom.
\end{abstract}

Key words: Theobroma cacao, genetic breeding, resistance, witches' broom disease

\section{FONTES DE RESITÊNCIA A Crinipellis perniciosa EM PROGÊNIES DE CACAUEIROS COLETADOS NA AMAZÔNIA BRASILEIRA}

RESUMO: A doença vassoura-de-bruxa, causada pelo fungo Crinipellis perniciosa, é o principal problema fitossanitário para o cultivo do cacaueiro no Brasil. O manejo integrado da doença envolve a resistência como um dos componentes. O programa de melhoramento genético do cacaueiro conduzido pela Instituição brasileira CEPLAC é direcionado para acumular genes de resistência de diferentes fontes visando à obtenção de uma resistência mais durável. O objetivo deste estudo foi identificar novas fontes de resistência em progênies de acessos de cacau da Amazônia brasileira. Os acessos foram coletados em dez bacias hidrográficas da Amazônia e comparados com progênies de 'Scavina 6' e 'Scavina 12', do Peru. Progênies de 40 acessos amazônicos e de 'Scavina' foram avaliadas no campo por seis anos para resistência à vassoura-de-bruxa, através de análise multivariada e de medidas repetidas considerando os efeitos de progênie, ensaio, bloco, ano e suas interações. Houve diferenças no número de vassouras vegetativas em algumas das progênies amazônicas e de 'Scavina'. Houve também incremento no número de vassouras para os descendentes de 'Scavina' no último ano do experimento, fato não observado para as progênies dos clones amazônicos 64, 66, 156, 194, 195, 269 e 274. Existem diferentes genes/alelos de resistência em progênies amazônicas e em descendentes do tradicional 'Scavina'. As novas fontes de resistência serão importantes para a piramidação de genes/alelos para a ampliação da estabilidade e durabilidade da resistência.

Palavras-chave: Theobroma cacao, melhoramento genético, resistência, avaliação de campo, vassourade-bruxa

Sci. Agric. (Piracicaba, Braz.), v.63, n.6, p.572-578, November/December 2006 


\section{INTRODUCTION}

Cacao (Theobroma cacao) is a perennial species that grows spontaneously in the tropical plains of South America (Cuatrecasas, 1964); it is grown mainly in the Amazonian region and in Bahia State in Brazil, one of the world's five largest producers of cacao. Diseases are responsible for the largest losses in production in the last two decades (Bowers et al., 2001).

The basidiomycete Crinipellis perniciosa, causal agent of the witches' broom disease, is one of the most damaging cacao pathogens. The fungus infects all meristematic tissues, including flower cushions, pods, and growing parts of the stem (Silva et al., 2002). Infected stems produce the vegetative brooms, which are hypertrophyc and hyperplasic branches possibly caused by hormonal imbalances induced by the pathogen. This disease was detected in the main Brazilian cacao-growing region, Bahia State, in 1989 (Pereira et al., 1990). Witches' broom disease caused up to $90 \%$ losses in some cacao crops (Luz et al., 2005), leading to unemployment of rural workers and the destruction of what remains of the Atlantic forest (Trevizan \& Marques, 2002). The disease control should ideally involve the use of resistant genotypes. Progress in cacao breeding programs around the world are considered poor in comparison to other crops, possibly because of the small number of studies on sources of resistance from wild cacao accessions (Rios-Ruiz, 2001).

The search for resistance to witches' broom in South America began in the 1930's, through collecting-expeditions to the Amazonian region, including areas in Ecuador, Peru, and Colombia. During these expeditions, pods of wild cacao apparently free from the disease were collected and their progenies introduced mainly into Trinidad (Fonseca, 1988). The best sources of resistance, the accessions 'Scavina 6' and 'Scavina 12' were obtained in Peru by Pound (1938; 1943). These accessions showed immunity to the disease in Trinidad (Bartley, 1994), susceptibility in Ecuador (Bartley, 1981), Peru (Rios-Ruiz, 1989), and in Rondônia State, Brazil (Anderbrhan et al., 1998). The 'Scavina 6' accession is widely used by the Comissão Executiva do Plano da Lavoura Cacaueira - CEPLAC's breeding program. However, because of the variable reactions of these accessions in other regions and to the existence of genetic variations of the pathogen population in Bahia State (Pires, 2003), the breeding programs need to incorporate new sources of resistance as a strategy to obtain extended resistance (Pinto \& Pires, 1998).

The Brazilian Amazon harbors great part of the cacao genetic diversity. Accessions with a wide variation in terms of vigour, morphological characteristics, productivity, and disease resistance were collected in that region (Vello \& Medeiros, 1965; Barriga et al., 1985; Almeida \& Almeida, 1987; Almeida et al., 1987; 1995; Bartley et al., 1988; Almeida \& Dias, 2001), mainly in the States of Acre, Rondônia, and Amazonas, (Almeida, 1996; Almeida et al., 1987). These accessions were termed CAB (cacao from the Brazilian Amazon) and maintained as part of CEPLAC's germplasm. In 1997, open pollinated pods from 40 selected accessions were introduced in Bahia State to be evaluated for witches' broom resistance (Luz et al., 1997; 2000). Seedlings from these accessions were selected for witches' broom resistance in greenhouse through artificial inoculation (Luz et al., 1997; 2000). Greenhouse-selected plants evaluated under field conditions were the basis of the present study, targeted at evaluating resistance to witches' broom disease on cacao progenies obtained from 40 accessions collected from ten river basins in the Brazilian Amazon.

\section{MATERIAL AND METHODS}

\section{Field experiments}

Seedlings from 40 cacao accessions collected in different Amazonian regions were used (Table 1). From seedlings not showing symptoms of witches' broom in the greenhouse (Luz et al., 1997; 2000), 36 individuals from each progeny were transferred to the field six months after germination along with the same number of seedlings of 'Scavina 6' and 'Scavina 12' progenies, used as resistant controls, and of 'Catongo', used as susceptible control. The field experiments were installed in 1997, in three areas at CEPLAC, Ilhéus, Bahia State, Brazil (18 progenies in the first area, 10 in the second and 13 in the third, plus the three controls in all areas - Table 1). The three experiments were set up in a randomized blocks design, with three replicates of 12 plants per plot spaced $3.0 \times 1.5 \mathrm{~m}$, and planted under older cacao trees highly infected with C. perniciosa. Plants were evaluated individually every three months for six years (1999 to 2004) for witches' broom symptoms, yield, and other agronomical traits. The number of vegetative brooms on 30 cacao trees, used as natural inoculum sources and under which the evaluated seedlings were planted was taken once in 2005 for comparison purposes.

\section{Statistical analysis}

The number of vegetative brooms per plant per year was the variable here analyzed. To simplify presentation of the results, the three experiments were evaluated jointly, as elicited by the use of the controls in all experiments and the lack of interaction between controls and areas allowed (Pimentel-Gomes, 1990). 
Table 1 - Cacao accessions evaluated for witches' broom resistance under field conditions for six years at CEPLAC/ CEPEC.

\begin{tabular}{|c|c|c|c|}
\hline Origin & River basin & Accession $^{\mathrm{a}}$ & Area $^{\mathrm{b}}$ \\
\hline \multirow[t]{11}{*}{ Amazonas State, Brazil } & Japurá/Solimões & CAB 264, 265, 266, 269 & 1 \\
\hline & & CAB 526 & 2 \\
\hline & Japurá & CAB 486 & 3 \\
\hline & Acre & CAB 160 & 2 and 3 \\
\hline & Solimões/Amazonas & CAB $271,272,273,274,275$ & 1 \\
\hline & & CAB 5336/16, 5336/19, 329/05 & 2 \\
\hline & & CAB $327,328,329$ & 3 \\
\hline & Solimões & CAB 334 & 3 \\
\hline & Içá & CAB 364 & 3 \\
\hline & Itaquaí & CAB 356 & 3 \\
\hline & Purus & CAB $191,193,194,195$ & 1 \\
\hline \multirow[t]{3}{*}{ Acre State, Brazil } & Acre & CAB $145,148,154,156$ & 2 \\
\hline & Acre & CAB 153 & 2 and 3 \\
\hline & Caeté/Iaco & CAB $64,65,66,67,69$ & 1 \\
\hline Rondônia State, Brazil & Jamarí & CAB $219,221,233,383,388$ & 3 \\
\hline Peru & Ucayali & SCA 6, SCA 12 & 1,2 and 3 \\
\hline Bahia State, Brazil & Catongo & & 1,2 and 3 \\
\hline
\end{tabular}

${ }^{\mathrm{a}} \mathrm{CAB}$ stands for cacao from the Brazilian Amazon and SCA for 'Scavina'.

'Area within experimental station 'Arnaldo Medeiros' where the progenies of a determined accession were planted. Divided into 1, 2, and 3.

Furthermore, the main objective of this study was to compare the Amazonian progenies with the 'Scavina' controls. Multivariate analyses were used to study the effects of area, block within the areas, progeny, and interactions between controls and areas by considering the mean value of vegetative brooms per plant per year as separate variables. The interpretation of the effect of the year and the effects of interactions between year and area and progeny was done with the analyses of repeated measurements (Danford, 1960). To better understand the interaction progeny $\mathrm{x}$ year, each of the six years was successively removed from the analyses, enabling the comparison of individual contributions to the interaction. All studied progenies were compared through contrasts with 'Scavina 6' and the Amazonian progeny with the lowest number of vegetative brooms. All analyses were done with the program SAS (SAS Institute, 1988).

\section{RESULTS}

\section{Controls}

Because only six out of 108 plants (36 plants per area) of the Catongo progeny, used as susceptible control, survived to the Crinipellis perniciosa inoculum pressure, this control was not considered.

\section{Joint evaluation of the areas}

The interaction between controls and areas was not significant $(P=0.1981$; Wilk's test), allowing the combined analysis of the areas as a single experiment (Pimentel-Gomes, 1990).

\section{Number of vegetative brooms}

Effects of area and blocks within the areas were significant $(P<0.0001$; Wilk's test $)$. Therefore the average number of vegetative brooms for the progenies was corrected for these factors. The mean number of vegetative brooms per year differed among progenies $(P<0.0001$; Wilk's test $)$. The highest average number of vegetative brooms per plant per year (total of four evaluations per year) among all progenies studied was 22.6 brooms (average observed in 2004 for the Amazonian progeny 272). On the other hand, the mean number observed for thirty randomly selected plants among the ones kept in the experiment as inoculum sources was 71.8 vegetative brooms per plant in only one observation.

\section{Year effect}

The interaction between years and progenies was significant ( $P=0.0001$; Wilk's test). The removal of one of the six years from the analyses, lead to $\mathrm{F}$ values of 3.3734, 3.7888, 3.9941, 3.6096, 3.3031, and 
Table 2 - Adjusted mean number of vegetative brooms on Amazonian (CAB) and 'Scavina' (SCA) progenies evaluated for six years at CEPLAC/CEPEC.

\begin{tabular}{|c|c|c|c|c|c|c|}
\hline \multirow{2}{*}{ Progenies } & \multicolumn{6}{|c|}{ Evaluation year } \\
\hline & 1999 & 2000 & 2001 & 2002 & 2003 & 2004 \\
\hline CAB 064 & 7. 45 & 3.22 & 0.61 & -0.12 & -0.05 & -0.35 \\
\hline CAB 065 & 5. 71 & 9. 05 & 2. 72 & 1. 82 & 0.26 & 4. 65 \\
\hline CAB 066 & 5. 58 & 3. 72 & -0.22 & -0.76 & -0.86 & -1.79 \\
\hline CAB 067 & 4. 60 & 6.39 & 1. 34 & 1. 24 & -0.28 & 4. 07 \\
\hline СAB 069 & 4. 86 & 4. 44 & 1. 92 & 1. 78 & -0.09 & 2. 39 \\
\hline CAB 145 & 4. 97 & 7. 00 & 2. 26 & 3. 55 & 1. 01 & 6. 05 \\
\hline CAB 148 & 5. 31 & 7. 78 & 1. 17 & 2. 61 & 0.96 & 4. 97 \\
\hline CAB 153 & 2. 39 & 2. 33 & 0.71 & 2. 16 & 1. 04 & 5. 59 \\
\hline CAB 154 & 4. 90 & 5. 94 & 1. 50 & 3.33 & 1.05 & 5. 53 \\
\hline CAB 156 & 3. 37 & 4. 75 & 0.78 & 2. 10 & 0.60 & 3. 00 \\
\hline CAB 160 & 4. 98 & 4. 84 & 1. 18 & 3. 29 & 1. 43 & 6. 62 \\
\hline CAB 191 & 7. 53 & 7. 69 & 2. 80 & 6. 19 & 1. 28 & 4. 68 \\
\hline САВ 193 & 6. 84 & 4. 84 & 1. 69 & 3. 13 & 1. 25 & 8. 21 \\
\hline CAB 194 & 2. 95 & 3. 42 & 0.12 & 0.28 & -0.04 & -1.59 \\
\hline CAB 195 & 3. 49 & 3. 00 & -0.08 & -0.95 & -0.83 & -3.15 \\
\hline CAB 219 & 1. 92 & 1. 93 & 0.71 & 2. 20 & 0.72 & 4. 46 \\
\hline CAB 221 & 2. 48 & 1. 34 & 0.54 & 1. 75 & 0.80 & 2. 77 \\
\hline CAB 233 & 2. 76 & 3.77 & 0.84 & 2. 28 & 1. 18 & 4. 01 \\
\hline CAB 264 & 9. 96 & 9.66 & 2. 15 & 3.33 & 0.35 & 7. 11 \\
\hline CAB 265 & 8. 40 & 5.33 & 1. 34 & 1. 88 & 0.11 & 5. 24 \\
\hline CAB 266 & 7. 73 & 5. 04 & 1. 09 & 1. 40 & 0.46 & 2. 32 \\
\hline CAB 269 & 4. 17 & 2. 57 & 0.43 & 0.36 & -0.41 & -0.73 \\
\hline CAB 271 & 5. 52 & 6. 97 & 1. 85 & 3. 41 & 1. 94 & 7. 58 \\
\hline CAB 272 & 7. 34 & 8. 00 & 5. 14 & 10. 44 & 2. 26 & 22. 59 \\
\hline CAB 273 & 6. 64 & 6. 03 & 0. 19 & 0.17 & 0.49 & 4. 75 \\
\hline CAB 274 & 3. 25 & 3. 85 & 0.73 & -0.30 & 0.34 & 3. 36 \\
\hline CAB 275 & 8. 93 & 9. 90 & 2. 19 & 4. 58 & 1. 22 & 10.82 \\
\hline CAB 327 & 5. 72 & 3. 96 & 1.23 & 3.35 & 3.25 & 10. 76 \\
\hline CAB 328 & 3. 75 & 2. 89 & 1. 00 & 2. 55 & 1. 00 & 5. 50 \\
\hline CAB 329 & 3. 56 & 2. 73 & 0.88 & 2. 26 & 1. 44 & 6. 89 \\
\hline CAB 334 & 3. 33 & 2. 54 & 0.85 & 2. 60 & 1. 51 & 6. 39 \\
\hline CAB 356 & 4. 42 & 3. 49 & 0.95 & 3. 06 & 1. 27 & 5. 32 \\
\hline CAB 364 & 2. 40 & 1. 64 & 0.71 & 2. 03 & 1. 48 & 5. 67 \\
\hline CAB 383 & 2. 26 & 3. 03 & 0.64 & 2. 14 & 1. 67 & 7. 53 \\
\hline CAB 388 & 2. 89 & 3. 16 & 0.73 & 3. 03 & 1. 23 & 4. 31 \\
\hline CAB 486 & 5.35 & 3. 98 & 1.76 & 3. 09 & 2. 53 & 9. 70 \\
\hline CAB 526 & 8. 21 & 11.65 & 4. 08 & 6. 11 & 3. 48 & 10. 35 \\
\hline CAB 329/05 & 7. 14 & 7. 70 & 2. 08 & 3. 50 & 1. 48 & 10. 33 \\
\hline CAB 5336/16 & 6. 61 & 14. 41 & 3. 30 & 8. 92 & 2. 11 & 11. 80 \\
\hline CAB 5336/19 & 4. 50 & 2. 84 & 1. 55 & 2. 73 & 1. 88 & 6. 10 \\
\hline SCA 12 & 2. 25 & 2. 29 & 0.97 & 2. 23 & 1. 81 & 8. 57 \\
\hline SCA 6 & 2. 12 & 1. 74 & 1. 02 & 2. 19 & 1. 26 & 6. 52 \\
\hline
\end{tabular}


3.2826 , respectively for years $1999,2000,2001,2002$, 2003 , and 2004, regarding the interaction progeny' year. The lowest $\mathrm{F}$ value was found after the removal of 2004, indicating that this year was the most important for the interaction. For the progenies descendant from 'Scavina 6' and '12' there was an absolute increase in disease intensity in 2004 (the 'Scavina's' averages of brooms per plant increased in relation to the averages of these same progenies in the previous years) and a proportional increase in 2002 and 2003 (some Amazonian progenies gained evidence in relation to 'Scavina's' progenies), while some Amazonian progenies such as 66, 194, and 195 did not show this increase (Table 2, Figure 1). The progenies from Amazonian accessions 145, 148, 154, 156, 160, 191, 193, 194, 195, 264, 265, 266, 269, 271, 272, 273, 274, 275, $327,329 / 05,486,526,64,65,66,67,69$, and 5336/ 16 were distinct from 'Scavina 6' progenies at $P<0.05$ (Table 3). Among these progenies, 64, 66, 156, 194, 195, 269, and 274 showed general mean number of vegetative brooms lower than 'Scavina 6' progenies along the 6 years (data not shown). From a total of 39 contrasts between progenies from 195 and the other Amazonian progenies, 31 were statistically significant at $P<0.05$ (Table 3). These contrasts demonstrated the existence of differences between the superior (significantly distinct from 'Scavina') Amazonian progenies, e.g. 195 and 64 (Table 3). The progeny 195 showed the lowest number of vegetative brooms per plant and did not show any increase in 2004 (Table 2).

\section{DISCUSSION}

The Amazonian progenies included genotypes of great resistance once they passed through an initial selection at CEPLAC's ERJOH station (Fonseca \& Albuquerque, 1996), followed by another one in the greenhouse (Luz et al., 1997), and were finally selected in the field by the mortality of susceptible plants

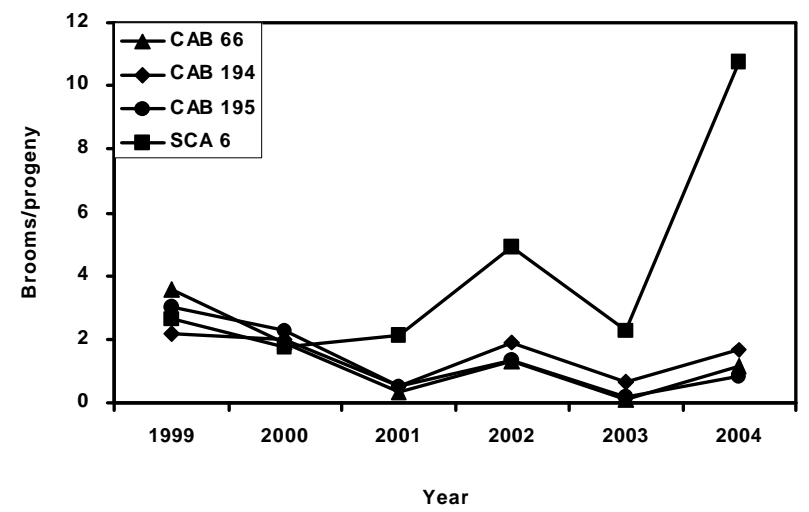

Figure 1 - Mean number of vegetative brooms in selected Amazonian $(\mathrm{CAB})$ progenies compared to 'Scavina 6' (SCA 6) progenies during six years.
Table 3 - Contrasts between all Amazonian (CAB) and 'Scavina' (SCA) progenies versus CAB 195 and SCA 6.

\begin{tabular}{|c|c|c|}
\hline Progenies & $\begin{array}{c}\text { SCA } 6 \\
P \mathrm{Pr}>\mathrm{F} *\end{array}$ & $\begin{array}{l}\text { CAB } 195 \\
P \text { r }>F^{*}\end{array}$ \\
\hline СAB 064 & 0.0001 & 0.0406 \\
\hline CAB 065 & 0.0005 & 0.0124 \\
\hline СAB 066 & 0.0001 & 0.6451 \\
\hline CAB 067 & 0.0004 & 0.0345 \\
\hline САВ 069 & 0.0056 & 0.1035 \\
\hline CAB 145 & 0.0016 & 0.0041 \\
\hline CAB 148 & 0.0001 & 0.0191 \\
\hline CAB 153 & 0.9131 & 0.0012 \\
\hline CAB 154 & 0.0304 & 0.0235 \\
\hline CAB 156 & 0.0455 & 0.1311 \\
\hline CAB 160 & 0.0072 & 0.0010 \\
\hline СAB 191 & 0.0001 & 0.0001 \\
\hline СAB 193 & 0.0009 & 0.0001 \\
\hline CAB 194 & 0.0029 & 0.7669 \\
\hline СAB 195 & 0.0001 & - \\
\hline CAB 219 & 0.9034 & 0.0018 \\
\hline CAB 221 & 0.6197 & 0.0671 \\
\hline CAB 233 & 0.5160 & 0.0295 \\
\hline CAB 264 & 0.0001 & 0.0001 \\
\hline CAB 265 & 0.0001 & 0.0001 \\
\hline CAB 266 & 0.0001 & 0.0712 \\
\hline CAB 269 & 0.0002 & 0.8381 \\
\hline CAB 271 & 0.0111 & 0.0001 \\
\hline CAB 272 & 0.0001 & 0.0001 \\
\hline CAB 273 & 0.0001 & 0.0043 \\
\hline CAB 274 & 0.0355 & 0.1251 \\
\hline CAB 275 & 0.0001 & 0. 0001 \\
\hline CAB 327 & 0.0008 & 0.0001 \\
\hline CAB 328 & 0.7053 & 0.0344 \\
\hline CAB 329 & 0.8508 & 0.0088 \\
\hline CAB 334 & 0.8467 & 0. 0042 \\
\hline CAB 356 & 0.1784 & 0.0118 \\
\hline CAB 364 & 0.9740 & 0.0100 \\
\hline CAB 383 & 0.7871 & 0.0010 \\
\hline CAB 388 & 0.4841 & 0.0157 \\
\hline CAB 486 & 0.0356 & 0.0001 \\
\hline CAB 526 & 0.0001 & 0. 0001 \\
\hline CAB 329/05 & 0.0001 & 0.0002 \\
\hline CAB 5336/16 & 0. 0001 & 0. 0001 \\
\hline CAB 5336/19 & 0.1419 & 0.0015 \\
\hline Sca 12 & 0.4085 & 0.0001 \\
\hline Sca 6 & - & 0.0001 \\
\hline
\end{tabular}

*Probability of committing an error in accepting the hypothesis of difference between the progenies with six annual means of vegetative brooms. 
caused by high disease pressure. This resistance is illustrated by the low number of vegetative brooms on Amazonian progenies, the highest average being 22.6 vegetative brooms per plant per year (272, year 2004; Table 2).

The differences among progenies in regard to the mean number of vegetative brooms per year indicates that different genes/alleles of resistance might be expressing in these progenies. The existence of interaction between year of evaluation and progenies shows that these progenies behaved differently along the years, 2004 being the most important year for the interaction. In this year, there was an increase in the number of vegetative brooms for 'Scavina 6' and '12' progenies; the same trend was not observed for the progenies of 64, 66, 156, 194, 195269 and 274 (Table 2, Figure1). These progenies have different averages of vegetative brooms per year in comparison to 'Scavina 6' $(P>0.05$; Wilks Test; Table 3$)$ and a lower mean number of vegetative brooms than 'Scavina 6' progenies (data not shown) along the six years, what demonstrates, again, the presence of different genes/alleles of resistance.

Apart from the different genetic structure for the resistance in some Amazonian progenies and 'Scavina 6', apparently differences among superior progenies, as seen for 195 and 64 (Table $3-P$ > 0.0406 ) also occur. These differences indicate a differential reaction to the disease and imply in the expression of different resistance genes/allelles.

The changes in the resistance pattern of 'Scavina' descendants were already observed in the proximity of the areas where this experiment was conducted, and also a clear distinction between isolates of C. perniciosa obtained from susceptible and resistant cacao genotypes according to RAPD markers (Pires, 2003). This adaptation of the fungus to 'Scavina' might also have occurred in the areas where the experiments were installed.

Therefore, two aspects are important to emphasize: 1) once changes in the pattern of disease resistance in 'Scavina' progenies were recorded again, the need for new resistance genes and their association aiming at the amplification of the genetic diversity in the field and the achievement of a more durable resistance is confirmed; and 2) the identification of Amazonian progenies with genes/alleles of resistance different from those of 'Scavina 6', will allow the necessary association of them.

\section{ACKNOWLEDGEMENTS}

To CEPLAC's phytopathology team: Denise Argolo Ferreira, Joel Feitosa, Magnaldo Nascimento,
Vanessa Paim, Cenilda Rocha, Márcia Paim, Víginia Damaceno for the field data collection, and to Dr. José Luíz Bezerra, Dr. Milton Macoto Yamada, Dr. Ronan Xavier Corrêa, Dr. Karina P. Gramacho, and Eduardo Paim for their suggestions.

\section{REFERENCES}

ALMEIDA, C.M.V.C. Aspectos ecológicos e evolutivos do cacaueiro (Theobroma cacao L.) da Amazônia brasileira. Agrotrópica, v.8, p.1-14, 1996.

ALMEIDA, C.M.V.C.; ALMEIDA, C.F.C. Coleta de cacau silvestre no Estado de Rondônia, Brasil. Revista Theobroma, v.17, p.65-92, 1987.

ALMEIDA, C.M.V.C.; DIAS, L.A.S. Recursos genéticos. In: DIAS, L.A.S., (Ed.) Melhoramento genético do cacaueiro. Viçosa: FUNAPE, 2001. p.163-216.

ALMEIDA, C.M.V.C.; BARRIGA, J.P.; MACHADO, P.F.R.; BARTLEY, B.G.D. Evolução do programa de conservação dos recursos genéticos de cacau na Amazônia Brasileira. Belém: CEPLAC, DEPEA, 1987. 108p. (Boletim Técnico, 5).

ALMEIDA, C.M.V.C.; MACHADO, P.F.R.; BARRIGA, J.P.; SILVA, F.C.O.D. Coleta de cacau (Theobroma cacao L.) da Amazônia Brasileira: uma abordagem histórica e analítica. Porto Velho: CEPLAC, SUPOC, 1995. 92p.

ANDERBRHAN, T.; ALMEIDA, L.C.; NAKAYAMA, H.I. Resistência de Theobroma cacao L. a Crinipellis perniciosa (Stahel) Singer: A experiência da Amazônia Brasileira. Agrotrópica, v.10, p.49-60, 1998.

BARRIGA, J.P.; MACHADO, P.F.R.; ALMEIDA, C.M.V.C.; ALMEIDA, C.F.G. Preservação e utilização dos recursos genéticos de cacau na Amazônia Brasileira. In: INTERNATIONAL COCOA RESEARCH CONFERENCE, 9., London, 1985. Proceedings. London: Cocoa Producers'Alliance, 1985. p.73-79.

BARTLEY, B.G.D. Status of genetic resistance in cacao to Crinipellis perniciosa (Stahel) Singer. In: INTERNATIONAL COCOA RESEARCH CONFERENCE, Lagos, 1981. Proceedings. Lagos: Cocoa Producers'Alliance, 1981. p.57-69.

BARTLEY, B.G.D. A review of cacao improvement. Fundamental methods and results. In: INTERNATION WORKSHOP ON COCOA BREEDING STRATEGIES, Kualla Lumpur, 1994. Proceedings. Kualla Lumpur, 1994. p.16.

BARTLEY, B.G.D.; MACHADO, P.F.R.; AHNERT, D.; BARRIGA, J.P.; ALMEIDA, C.M.V.C. Descrição de populações de cacau da Amazônia brasileira. I - observações preliminares sobre populações de Alenquer, Pará. In: INTERNATIONAL COCOA RESEARCH CONFERENCE, 10, London, 1988. Proceedings. London: Cocoa Producers'Alliance, 1988. p.665-672.

BOWERS, H.J.; BAYLEY, B.A.; HEBBAR, K.P.; SANOGO, S.; LUMSDEN, R.D. The impact of plant diseases on world chocolate production. Plant Health Progress, 2001. Available in: http:// www.apsnet.org/online/feature/cacao/. Accessed: 10 out. 2005.

CUATRECASAS, J. Cacao and its allies: a taxonomic revision of the genus Theobroma. Contributions of the United States National Herbarium, v.35, p.379-614, 1964.

DANFORD, M.B.; HUGES, H.M.; McNEE, R.C. On the analysis of repeated measurement experiments. Biometrics, v.16, p.547-565, 1960.

FONSECA, S.E.A. Assessing resístance to Crinipellis perniciosa in cocoa accesses and callus cultures. Berkshire: University of London, 1988. 250p. (Doctor - Thesis).

FONSECA, S.E.A.; ALBUQUERQUE, P.S.B. Avaliação de clones de cacau na Amazônia brasileira em relação a incidência de vassourade-bruxa. In: INTERNATIONAL COCOA RESEARCH CONFERENCE, 12, Salvador, 1996. Proceedings. Salvador: Cocoa Producers'Alliance, 1996. p.149-153.

LUZ, E.D.M.N.; SILVA, S.D.V.M.; LOPES, U.V.; GRAMACHO, K.P.; PINTO, L.R.M. Seleção de material genético de cacaueiro resistente à vassoura-de-bruxa na Bahia. Fitopatologia Brasileira, v.22, p.279279, 1997. Suplemento. 
LUZ, E.D.M.N.; SILVA, S.D.V.M.; GRAMACHO, K.P.; LOPES, U.V.; ALBUQUERQUE, P.S.B. Cocoa progenies responses to Crinipellis perniciosa under field and controlled environment conditions in Bahia, Brazil. In: INTERNATIONAL COCOA RESEARCH CONFERENCE, 13, Kota Kinabalu, 2000, Proceedings. Kota Kinabalu: Producers'Alliance, 2000. p.537-543.

LUZ, E.D.M.N.; SGRILLO, R.B.; SANTOS FILHO, L.P. Estimativas de danos e perdas causadas por doenças no cacaueiro. In: WORKSHOP DE EPIDEMIOLOGIA DE DOENÇAS DE PLANTAS, 1. Viçosa, 2004. Proceedings. Viçosa: Editora UFV, 2005. p.67-79.

PEREIRA, J.L.; RAM, A.; FIGUEIREDO, J.M.; ALMEIDA, L.C.C. First occurrence of witches' broom disease in the principal cocoagrowing region of Brazil. Tropical Agriculture, v.67, p.188-189, 1990.

PIMENTEL-GOMES, F.P. Curso de estatística experimental. Piracicaba: Degaspari, 1990. 437p.

PINTO, L.R.M.; PIRES, J.L. Seleção de plantas de cacau resistentes à vassoura-de-bruxa. Ilhéus: CEPLAC/CEPEC, 1998. 35p. (Boletim Técnico, 181).

PIRES, J.L. Avaliação quantitativa e molecular de germoplasma para o melhoramento do cacaueiro com ênfase na produtividade, qualidade de frutos e resistência a doenças. Viçosa: UFV, 2003. 226p. (Tese Doutorado).

POUND, F.J. Cacao and witches'broom disease (Marasmius perniciosus) of South America, with notes on other species of Theobroma: report on a visit to Ecuador, the Amazon Valley and Colombia. Port of Spain: American Cocoa Research Institute, 1938. 58p. (Archives of Cocoa Research).
POUND, F.J. Cacao and witches' broom disease (Marasmius perniciosus): report on a recent visit to the Amazon territory of Peru. In: RHODES, A.L. (Ed.). Cacao agronomist. Port of Spain: Government Printer, Department of Agriculture, 1943. 14p.

RIOS-RUIZ, R.A. Manejo de enfermedades em cacao y café en Tingo Maria. Tingo Maria: OSP/PNUD, 1989. 89p. (Relatório de Consultoria).

RIOS-RUIZ, R.A. Melhoramento para resistência a doenças. In: DIAS, L.A.S. (Ed.). Melhoramento genético do cacaueiro. Viçosa: FUNAPE, 2001. p.289-324.

SAS INSTITUTE. SAS/STAT User's Guide. Release 6.03. Cary: Statistical Systems Institute, 1988. 1028p.

SILVA, S.D.V.M.; LUZ, E.D.M.N.; ALMEIDA, O.C.; GRAMACHO, K.P.; BEZERRA, J.L. Redescrição da sintomatologia causada por Crinipellis perniciosa em cacaueiros. Agrotropica, v.14, p.1-24, 2002.

TREVIZAN, S.D.P.; MARQUES, M. Impactos socioeconomicos da crise do cacau: um estudo de comunidade-caso. Agrotropica, v.14, p.127136,2002

VELLO, F.; MEDEIROS, A.G. Expedição botânica à Amazônia Brasileira. Cacau Atualidades, v.2, p.47-51, 1965.

Received February 17, 2006

Accepted November 06, 2006 